\title{
PENGEMBANGAN BAHAN AJAR DALAM PEMBELAJARAN SEJARAH KEBUDAYAAN ISLAM BERBASIS OBSERVASI DI SMK MULYA BHAKTI MANDIRI CIANJUR
}

\author{
Hendra Wira Candra' ${ }^{1)}$,Muhammad Rijaal Qurrota A'yuni' ${ }^{2)}$ \\ ${ }^{1)}$ Smp Mutiara Bunda, Bandung, 40416 Pascasarjana UIN Sunan Gunung \\ Djati Bandung Email: Muhammadrijaal003@Gmail.Com \\ ${ }^{2)}$ Smp Daarut Tauhiid Boarding School, Bandung, 40559, Pascasarjana \\ UIN Sunan Gunung Djati Bandung, Email: \\ Azzamsyahidabdullah@Gmail.Com
}

\begin{abstract}
The development of learning models in the present makes education more advanced and facilitates learning itself. So students can more easily accept and digest lessons from their teachers. The relationship between teacher and student must be dynamic and requisite with education. For that the use of learning models should be able to enable for changes in students themselves in learning activities, for that approach and learning model should be well designed for learning to achieve maximum results. This study aims to produce teaching materials of Islamic education based on observation with learning models that enable students. The research method used is interview, observation, and docemntasi. Data analysis used is descriptive analysis.
\end{abstract}

Keywords:

Materials Teaching, Mining, Approach, Observation

\begin{abstract}
Abstrak : Berkembangnya model pembelajaran pada masa kini membuat pendidikan lebih maju dan mempermudah pembelajaran itu sendiri. Sehingga siswa dapat lebih mudah menerima dan mencerna pelajaran dari gurunya. Hubungan antara guru dan siswa harus bersifat dinamis dan syarat dengan edukasi. Untuk itu penggunaan model pembelajaran harus mampu mengaktifkan agar terdapat perubahan pada diri siswa dalam kegiatan belajar, untuk itu pendekatan dan model pembelajaran harus dirancang dengan baik agar pembelajaran dapat mencapai hasil yang maksimal. Penelitian ini bertujuan untuk menghasilkan bahan ajar pendidikan Agama Islam berbasis observasi dengan model pembelajaran yang mengaktifkan siswa. Adapun metode penelitian yang digunakan yaitu wawancara, pengamatan, dan dokemntasi. Analisis data yang digunakan yaitu analisis deskriptif.

Kata kunci:

Bahan Ajar, Pengambangan, Pendekatan, Observasi
\end{abstract}

\section{PENDAHULUAN}

Pendidikan Islam merupakan suatu proses pembentukan individu berdasarkan ajaran-ajaran Islam yang diwahyukan Allah SWT, kepada Muhammad SAW, melalui proses dimana individu dibentuk agar mendapat mencapai drajat yang tinggi sehingga ia mampu menunaikan tugasnya sebagai khalifah dimuka bumi, yang dalam krangka lebih lanjut mewujudkan kebahagiaan di dunia dan akhirat.(Azyumardi Azra, 2001: 6)

Kesadaran beragama yang mengkristal dalam pribadi orang yang beriman dan bertakwa adalah wujud dari kepatuhannya terhadap Allah Swt. Kepatuhan ini dilandasi oleh keyakinan dalam diri seseorang mengenai pentingnya seperangkat nilai relegius yang dianut. Karena kepatuhan, maka niat, ucap, pikir, tindakan, perilaku dan tujuan 
senantiasa diupayakan berada dalam lingkup nilai-nilai yang diyakini. Apabila hal itu dikaitkan dengan tujuan akhir Pendidikan Agama Islam (PAI) dalam mencapai manusia yang beriman dan bertaqwa serta memiliki akhlak yang mulia, maka kesadaran beragama memiliki peran yang signifikan dalam mencapai tujuan tersebut.

Belajar pada hakikatnya adalah proses interaksi terhadap semua situasi yang ada di sekitar individu. Belajar dapat dipandang sebagai proses yang diarahkan kepada tujuan dan proses berbaut melalui berbagai pengalaman. Belajar juga merupakan proses melihat, mengamati, dan memahami sesuatu (Sudjana, 1989: 28).

Kegiatan pembelajaran dilakukan oleh dua orang pelaku, yaitu guru dan siswa. Perilaku guru adalah mengajar dan perilaku siswa adalah belajar. Perilaku mengajar dan perilaku belajar tersebut terkati dengan penggunaan model pembelajaran yang mengaktifkan siswa.

E. Mulyasa mengungkapkan guru merupakan komponen yang paling berpengaruh terhadap terciptanya proses dan hasil pendidikan yang berkualitas. Oleh karena itu, upaya perbaikan apapun yang dilakukan untuk meningkatkan kualitas pendidikan tidak akan memeberikan sumbangan yang signifikan tanpa didukung oleh guru yang professional dan berkualitas (E. Mulyasa, 2008: 5)

Setiap guru harus memenuhi persyaratan sebagai manusia yang bertanggung jawab dalam bidang pendidikan. Guru sebagai pendidik bertanggung jawab untuk mewariskan nilai-nilai dan norma-norma kepada generasi berikutnya sehingga terjadi proses konservasi nilai, karena melalui proses pendidikan di usahakan terciptanya nilainilai baru.

Pembelajaran merupakan suatu sistem, yang terdiri dari berbagai komponen yang saling berhubungan satu dengan yang lain. Komponen tersebut meliputi tujuan, materi, metode, dan evaluasi. Keempat komponen pembelajaran tersebut haru selalu diperhatikan oleh guru dalam memilih dan menentukan model pembelajaran yang akan digunakan dalam kegiatan belajar mengajar.

Untuk mencapai tujuan dari pendidikan diperlukan upaya lebih dalam peningkatan mutu pendidikan di Indonesia yang masih tertinggal dari negara-negara lain. Sebagai ilustrasi dari segi pendidikan bangsa Indonesia saat ini masih terbelakang dalam lingkup Asia, bahkan dalam lingkup yang lebih kecil lagi di Asia Tenggara. Padahal pada tahun 1970-an, Malaysia misalnya masih mengimpor banyak guru dari Indonesia. Hal tersebut disebabkan oleh beberapa faktor menyebabkan kualitas pendidikan di Indonesia masih dikatakan rendah, antara lain sarana prasarana dan pendudkung kegiatan pendidikan yang masih kurang, tenaga pengajar yang kurang berkompetensi, serta masih banyak lagi kendala yang berpengaruh disamping faktor yang paling utama yakni kesadaran terhadap arti penting pendidikan itu sendiri di mata masyarakat bangsa Indonesia (Azhar Arsyad, 2011: 121).

Mata pelajaran Pendidikan Agama Islam yang biasa disingkat dengan PAI, termasuk salah satu mata pelajaran yang dianggap kurang menarik di mata siswa. Selain 
karena tidak masuk dalam daftar mata pelajaran yang diujikan secara nasional, guru mata pelajaran PAI sendiri umumnya menyampaikan materi dengan metode ceramah. Hal yang lebih kompleks lagi sekarang adalah banyaknya kegiatan guru di luar sekolah, sehingga siswa kadang tidak memperoleh materi dari gurunya.

Oleh karena itu, pembelajaran Sejarah Kebudayaan Islam yang merupakan bagian Pendidikan Agama Islam (PAI) harus mampu mencapai tujuan pendidikan Islam yang menjabarkan seluruh dimensi kehidupan manusia dan tidak boleh hanya memberi penekanan pada satu dimensi saja dan meninggalkan dimensi yang lainnya. Sehingga Sejarah Kebudayaan Islam tidak saja sekedar transfer of knowledge, tetapi juga merupakan pendidikan nilai (value education). Sehingga guru harus mampu dalam menggali nilai, makna, aksioma, ibrah/hikmah, dalil dan teori dari fakta sejarah yang ada. Selain hal tersebut juga guru mampu menemukan pendekatan yang dapat mempermudah transfer atau penguasaan materi sejarah kepada siswa.

Berbagai macam problematika pendidikan agama tersebut dihadapi oleh semua pihak baik keluarga, pemerintah, maupun masyarakat, termasuk di SMK Mulya Bhakti Mandiri Cianjur. Seperti bagaimana menentukan metode yang tepat untuk mengajarkan keimanan, bagaimana menentukan evaluasi yang tepat, bagaimana menanamkan nilainilai agama pada anak didik dalam pembelajaran Sejarah Kebudayaan Islam dan sebagainya.

Sebagai apresiasi permasalahan di atas maka peneliti merasa perlu melakukan penelitian terhadap kompetensi guru Sejarah Kebudayaan Islam. Adapun judul penelitian ini adalah PENGEMBANGAN BAHAN AJAR DALAM PEMBELAJARAN SEJARAH KEBUDAYAAN ISLAM BERBASIS OBSERVASI DI SMK MULYA BHAKTI MANDIRI CIANJUR.

\section{METODOLOGI}

Adapun metode yang digunakan adalah pendekatan kualitatif dengan menggunakan metode deskriptif-analitik. Yaitu dengan cara mengumpulkan data yang menggambarkan atau memaparkan apa adanya dari hasil penelitian kemudian disusun dan dituangkan dalam bentuk tulisan (naratif), ditafsirkan, dan dianalisis. Berdasarkan pada analisisnya jenis data dalam penelitian ini adalah data kualitatif. Data kualitatif merupakan sumber dari deskripsi yang luas dan berlandaskan kokoh, serta memuat penjelasan proses-proses yang terjadi dalam lingkup setempat.

Lexy Moleong mendefinisikan pendekatan kualitatif ini sebagai penelitian yang bermaksud untuk memahami fenomena tentang apa yang dialami oleh subjek penelitian misalnya perilaku, persepsi, motivasi, tindakan, dan lain-lain, secara holistik, dan dengan cara deskripsi dalam bentuk kata-kata dan bahasa, pada suatu konteks khusus yang alamiah dan dengan memanfaatkan berbagai metode alamiah (Lexy J Moleong, 2007: 6) 
Berdasarkan pada analisisnya jenis data dalam penelitian ini adalah data kualitatif. Data kualitatif merupakan sumber dari deskripsi yang luas dan berlandaskan kokoh, serta memuat penjelasan proses-proses yang terjadi dalam lingkup setempat. Dimana data tersebut berkaitan dengan Kompetensi Guru dalam Menginternalisasikan Nilai-Nilai Islam dalam Pembelajaran Sejarah Kebudayaan Islam pada SMK Mulya Bhakti Mandiri Cianjur.

Sedangkan jika di dasarkan pada sumbernya, maka jenis data pada penelitian ini dibagi menjadi dua varian yaitu :

a. Data primer, yaitu data yang diperoleh dari sumber asli (sumber pertama) atau data dari tangan pertama. Data primer digali dari sumber data yang dapat diperoleh dari lapangan secara langsung melalui observasi dan wawancara. Sumber data yang menjadi subyek dalam memberikan data yang diperlukan peneliti pada penelitian ini adalah :

1. Informan

Informan yang dimaksudkan oleh peneliti disini adalah orang yang telah menyampaikan informasi kepada peneliti tentang data-data yang diperlukan yang berhubungan dengan keberadaan SMK Mulya Bhakti Mandiri Cianjur serta proses pembelajaran dan pendidikannya, seperti Kepala Sekolah, Wakil Kepala, Dewan Guru, dan siswa SMK Mulya Bhakti Mandiri Cianjur. Kedudukan informan dalam penelitian kualitatif ini sangat penting. Posisi dan peranan informan dapat dikatakan sebagai "subyek" yang dapat memberikan informasi primer yang dibutuhkan peneliti. Melihat begitu sentralnya posisi dan peranan informan dalam penelitian, maka penetapan informan pun mutlak membutuhkan seleksi yang tidak sembarangan. Dalam konteks ini, penentuan informan disesuaikan dengan berbagai informasi yang dibutuhkan peneliti dengan merujuk kepada kompetensi mereka untuk dapat memberikan informasi mengenai permasalahan yang dikaji.

2. Responden

Responden pada penelitian ini adalah orang yang dapat diwawancarai pada waktu penelitian berlangsung yaitu guru-guru yang mengajar materi Sejarah Kebudayaan Islam di SMK Mulya Bhakti Mandiri Cianjur.

b. Data sekunder, yaitu data yang diperoleh bukan dari sumber, melainkan data dari hasil catatan tertulis yang memiliki relevansi dengan fokus masalah penelitian meliputi :

1. Buku-buku, Tesis, skripsi, yang relevan, mengenai kompetensi guru, nilainilai ajaran Islam, dan pembelajaran Sejarah Kebudayaan Islam

2. Dokumen-dokumen resmi secara tertulis tentang kompetensi guru, nilai-nilai ajaran Islam, dan pembelajaran Sejarah Kebudayaan Islam yang memiliki relevansi dengan fokus penelitian. Sumber data tertulis tersebut nantinya akan dieksplorasi dengan teknik dokumentasi dan kajian kepustakaan yang terdiri dari buku-buku dan majalah ilmiah, arsip dan dokumen pribadi. 
Hal ini mengindikasikan bahwa dalam penelitian kualitatif setidaknya ada tiga teknik yang biasa digunakan untuk mengumpulkan data-data, yaitu teknik dengan pengamatan (observasi), wawancara, dan dokumentasi. Untuk itu dalam penelitian ini peneliti menggunakan teknik pengumpulan data sebagai berikut:

a. Observasi Non Partisan (non-participant observation)Pengamat (observer) tidak ikut dalam kehidupan orang yang diobservasi dan secara terpisah berkedudukan selaku pengamat. Teknik ini peneliti gunakan untuk memperoleh data yang berkaitan dengan proses pembelajaran atau kegiatan belajar mengajar di kelas.

b. Wawancara, dengan wawancara ini dimaksudkan untuk mengetahui informasi secara detail dan mendalam dari responden dan informan dengan fokus masalah yang diteliti. Lincoln dan Guba (1985) seperti dikutip oleh Lexy Moleong menegaskan bahwa maksud wawancara antara lain adalah mengkonstruksi mengenai orang, kejadian, organisasi, perasaan, motivasi, tuntutan, kepedulian dan lain-lain kebulatan; merekonstruksi kebulatan-kebulatan demikian sebagai yang dialami masa lalu; memproyeksikan kebulatan-kebulatan sebagai yang diharapkan untuk dialami pada masa yang akan datang; memverivikasi, mengubah, dan memperluas informasi yang diperoleh dari orang lain, baik manusia maupun bukan manusia; dan memverifikasi, mengubah dan memperluas konstruksi yang dikembangkan oleh peneliti sebagai pengecekan anggota. Untuk membantu peneliti dalam memfokuskan masalah yang diteliti, dibuat pedoman wawancara dan pengamatan.

c. Dokumentasi, Teknik ini digunakan untuk mengumpulkan data yang sudah tersedia dalam catatan dokumen. Fungsinya sebagai pendukung dan pelengkap bagi data primer yang diperoleh melalui observasi dan wawancara. Dokumen yang dianggap relevan dalam penelitian ini meliputi struktur organisasi, keadaan siswa, keadaan guru, dan semua hal yang terkait dengan eksistensi SMK tersebut.

\section{HASIL KAJIAN DAN PEMBAHASAN}

Secara sederhana, Ahmad Tafsir memberikan pengertian pendidikan itu sebagai bimbingan yang diberikan kepada seseorang agar ia berkembang secara maksimal (Ahmad Tafsir: 27). Sedangkan Ahmad D. Marimba mengemukakan pengertian pendidikan sebagai bimbingan atau pimpinan secara sadar oleh si pendidik terhadap perkembangan jasmani dan rohani si terdidik menuju terbentuknya kepribadian yang utama (Ahmad D Marimba, 2001: 91)

Pendidikan Islam merupakan salah satu aspek dari ajaran Islam secara keseluruhan. Karenanya tujuan pendidikan Islam tidak terlepas dari tujuan hidup manusia dalam Islam, yaitu untuk menciptakan pribadi-pribadi hamba Allah yang selalu bertakwa kepada-Nya, dan dapat mencapai kehidupan yang bahagia di dunia dan akhirat.

Dengan demikian dapat disimpulkan bahwa pendidikan, khususnya Pendidikan Agama Islam adalah pendidikan yang secara integral dan sinergis serta konsisten selalu 
memperhatikan aspek eksoteris (lahiriah) dan esoteris (batiniah) manusia. Karena keduanya merupakan satu kesatuan integratif yang tidak dapat dipisahkan dan sekaligus menunjukkan eksistensi manusia. Ambivalensi dalam menata keduanya akan berakibat pada ketimpangan bertingkah laku dan pada gilirannya hanya akan melahirkan manusiamanusia yang berkepribadian ganda (split personality).

Untuk mewujudkan tercapainya peningkatan kualitas pendidikan dan upaya pencapaian tujuan pendidikan Islam, maka sangat dibutuhkan kompetensi guru. Guru yang memiliki kompetensi sangat menentukan keberhasilan peserta didik, terutama dalam kaitanya dalam proses belajar dan mengajar.

Nampak bahwa kompetensi mengacu pada kemampuan pada melaksanakan sesuatu yang diperoleh melalui pendidikan, kompetensi guru menunjukkan pada performance dan perbuatan yang rasional untuk memenuhi spesifikasi tertentu didalam melaksanakan tugas-tugas pendidikan. Dikatakan rasional karena mempunyai arah dan tujuan, sedangkan performance merupakan perilaku nyata dalam arti tidak hanya dapat diamati tetapi mencakup sesuatu yang tidak kasat mata.

Guru sebagai pelaku utama dalam implementasi atau penerapan program pendidikan di sekolah memiliki peranan yang sangat strategis dalam mencapai tujuan pendidikan yang diharapkan. Dalam hal ini, guru dipandang sebagai faktor determinan terhadap pencapaian mutu prestasi belajar siswa. Mengingat peranannya yang begitu penting, maka guru dituntut untuk memiliki pemahaman dan kemampuan secara komprehensif tentang kompetensinya sebagai pendidik.

Produktivitas kinerja guru yang baik akan membawa pengaruh yang baik pula terhadap keberhasilan pembelajaran yang dikelolanya, baik keberhasilan pembelajaran dilihat dari sudut proses (by process) maupun dilihat dari sudut hasil (by product). Kriteria keberhasilan dari sudut proses menekankan kepada pembelajaran yang berorientasi pada interaksi dinamis sehingga siswa sebagai subjek yang belajar mampu mengembangkan potensinya melalui belajar sendiri, dan tujuan yang telah ditetapkan tercapai secara efektif. Sedangkan kriteria keberhasilan dari segi hasil menekankan kepada tingkat penguasaan tujuan belajar oleh siswa baik dari segi kualitas maupun kuantitas (Ali Munfa'at, 2002: 38).

Kaitannya dengan proses pelaksanaan lembaga pendidikan Islam dalam rangka peningkatan kualitas pendidikan dan upaya pencapaian tujuan pendidikan Islam, maka peningkatan kualitas kompetensdi guru menjadi salah satu faktor yang menunjang keberhasilan tujuan pendidikan Islam. Maka, menjadi guru yang profesional yaitu, guru yang memiliki kinerja tinggi dalam menjalankan amanah keguruannya, yang memiliki kreativitas tinggi, yang selalu memikirkan bagaimana siswanya dapat menguasai ilmu pengetahuan, dan memiliki nilai-nilai keislaman atau berkeperibadian muslim.

Diantara nilai-nilai keislaman yang harus dimiliki oleh peserta didik adalah nialinilai akhlakul karimah. Menurut Capra (2004) dalam bukunya Titik Balik Peradaban menjelaskan bahwa pelajaran sejarah penting karena mengajarkan tentang nilai, moral, 
dan spiritual. Permasalahan yang kita hadapi dalam pembelajaran sejarah adalah rendahnya kemampuan guru dalam menerapkan berbagai model dan pendekatan dalam mengajar (http://history.multiply.com/journal/item, Akses, 28 Oktober 2008).

Idrus A Rore, menyatakan bahwa pembelajaran merupakan upaya menyiapkan anak didik untuk memperoleh pengetahuan, keterampilan, dan nilai (sikap) yang membawa perubahan tingkah laku maupun pertumbuhan sebagai pribadi (Idrus A Rore, 2007: 2).

Dengan demikian dapatlah dimengerti bahwa proses pembelajaran bukanlah berproses dalam kehampaan, tetapi berproses dalam kemaknaan, di dalamnya ada sejumlah nilai yang disampaikan kepada anak didik. Nilai-nilai itu tidak datang dengan sendirinya, tetapi terambil dari berbagai sumber guna dipakai dalam proses belajar mengajar.

Untuk itu dalam pembelajaran sejarah dapat lebih bermakna atau bernilai tinggi, apabila guru dapat menggunakan metode internalisasi nilai-nilai agama Islam di dalamnya, dengan cara mengaitkan materi sejarah dengan nilai-nilai ajaran agama atau dapat juga nilai-nilai yang terkandung dalam setiap peristiwa sejarah, dikaitkan dengan nilai-nilai yang terkandung dalam ajaran agama. Pendekatan ini akan membantu siswa dalam memahami dan menemukan nilai-nilai/makna peristiwa sejarah secara mendalam (ultimate meaning).

Sementara itu internalisasi merupakan suatu proses transformasi nilai-nilai yang dimiliki seseorang kepada orang lain sehingga orang tersebut memiliki nilai-nilai tersebut sebagai hasil dari proses internalisasi. Maka yang dimaksud dengan internalisasi nilai dalam penelitian ini pembauran atau penyatuan seperangkat keyakinan yang diyakini sebagai suatu yang benar, bermutu dan indah yang berdasarkan nilai-nilai Islam dan harus diyakini sebagai suatu identitas dalam pola pikir, perasaan maupun perilaku.

Salah satu indikator keberhasilan dan daya tarik pembelajaran di tentukan oleh kondisi lingkungan pembelajaran yang mencakup karakteristik pembelajaran, dan karakteristik siswa; sebagai sosok pribadi yang utuh yang memiliki dimensi individualitas dan sosialitasnya sesuai dengan tahap perkembangan yang dicapainya. Karakter ini sesuai dengan difinisi pembelajaran yang dikemukakan oleh Oemar Hamalik yaitu suatu kombinasi yang tersusun meliputi unsure-unsur manusiawi, material, fasilitas, perlengkapan, dan prosedur yang saling mempengaruhi untuk mencapai tujuan pembelajaran (Oemar Hamalik, 2003: 14)

Menurut hemat penulis, keberadaan SMK Mulya Bhakti Mandiri Cianjur sebagai SMK Model, salah satu bentuk lembaga pendidikan Kejuruan, menarik untuk dikaji, khususnya berkaitan dengan penerapan nilai-nilai ajaran Islam dalam pembelajaran Sejarah Kebudayaan Islam. Hal ini karena SMK Mulya Bhakti Mandiri Cianjur secara kualitatif relatif lebih baik dari SMK lainnya yang berada di sekitarnya, baik dari sisi infrastruktur, SDM, siswa dan lain sebagainya. Sekaligus SMK Mulya Bhakti Mandiri, secara geografis dekat dengan cagar budaya Gunung Padang Cianjur. 
Guru PAI menggunakan model pembelajaran yang mengaktifkan siswa dengan berbasis observasi ke salah satu cagar budaya nasional yaitu Gunung Padang, dengan pembahasan Sejarah Islam di Indonesia. Guru pun menggunakan pendekatan pembelajaran yang unik, yaitu penggunaan mega phone dan menghadirkan satu narasumber dari pihak gunung padang sendiri.

Narasumber menjelaskan materi yang erat kaitannya dengan gunung padang kemudian guru agama pun menjelaskan dari segi agama Islamnya. Hal ini menjadikan siswa lebih memperhatikan dan lebih menikmati pembelajaran.

Kemudian para siswa dibentuk menjadi beberapa kelompok dan diberi tugas atau pertanyaan seputar materi yang dibahas, kemudian didiskusikan dan dipresentasikan di depan teman-temannya.

\section{SIMPULAN}

Penerapan pembelajaran yang lebih mengaktifkan siswa dengan berbasis observasi ini dapat dilakukan melalui pengembangan berbagai keterampilan belajar esensial secara eklaktif yang antara lain sebagai berikut: (1) berkomunikasi lisan dan tertulis secara efektif, (2) berpikir logis, kritis, dan kreatif, (3) rasa ingin tahu, (4) penguasaan teknologi dan informasi, (5) pengembangan personal dan sosial, dan (6) belajar mandiri dan kelompok. Jadi pembelajaran bukanlah komunikasi satu arah (one way communication) transformasi dari guru kepada siswa saja, melainkan harus berupa komunikasi timbal balik secara interaktif antara siswa dengan guru. Dengan komunikasi tersebut siswa ditempatkan sebagai subjek dalam belajar, yang harus mendapatkan kesempatan secara luas untuk mengembangkan kreativitas, aktivitas, dan potensinya secara langsung dalam mencari, menemukan, dan memcahkan masalah pengalaman belajar.

\section{DAFTAR PUSTAKA}

Azra, Azyumardi, 2001 Pendidikan Islam, Tradisi dan Modernisasi Menuju Milinium Baru, (Jakarta : Kalimah)

Langgulung, Hasan, 2012, Pendidikan dan Peradaban Islam (Jakarta: Pustaka AlHusna)

Idrus A Rore, 2007, Metode Poker Suatu Alternatif Pengemabagan Daya Tarik Pelajaran Sejarah.

Mulyasa, 2008. Standar Kompetensi dan Sertifikasi Guru, (Bandung : Remaja Rosdakarya)

Rusman, 2014, MODEL-MODEL PEMBELAJARAN Mengembangkan Profesionalisme Guru, (Jakarta: Rajawali Pers)

Sudjana, Nana dan Ibrahim. 2004. Penelitian dan Penilaian Pendidikan. Bandung: Sinar Baru Algensindo. 
Pengembangan Bahan Ajar....

Tafsir, Ahmad. 2011. Ilmu Pendidikan dalam Persepektif Islam. Bandung: Remaja Rosdakarya.

---------, 2005. Ilmu Pendidikan dalam Perspektif Islam. (Bandung: Remaja Rosdakarya)

Oemar Hamalik, 2003, Kurikulum dan Pembelajaran, (Jakarta : Bumi Aksara). 